\title{
Building a Higher Education Area in Central Asia: challenges and prospects
}

\author{
Ann Katherine Isaacs
}

\begin{abstract}
In recent years, for a variety of reasons, higher education has begun to be considered much more frequently than previously in terms of 'regions', or 'macroregions'. Although for decades countries sharing some characteristics, or perceived as geographically or culturally closely related to each other, have promoted forms of cooperation between their higher education institutions (with varying degrees of success), it is now widely accepted that to 'count' on the world stage, it is useful for single countries, and especially for smaller countries, to work together with a view to making their systems better able to interact and hopefully to promote, increase and make visible their merits. Of course, in higher education as in many other fields, the regions or macro-regions are not defined once and for all, but are the result of stronger or weaker ad hoc groupings which take into account different factors in different contexts. Central Asia is one such potential region: it does not have unquestioned boundaries, but like other macro-regions, and more so than most, it can be understood and constructed in different ways. A current shared understanding of 'Central Asia' is that it is formed by the 4 ex-Soviet Republics of Central Asia (Kyrgyzstan, Tajikistan, Turkmenistan and Uzbekistan), plus Kazakhstan. Over the last decade the possibility of building a Higher Education Area in those five republics has been explored, and a large-scale project which uses Tuning methodology to this end is under way. This project, called TuCAHEA ("Towards a Central Asian Higher Education Area: Tuning Structures and Building Quality Culture"), has already elaborated a Central Asian list of Generic Competences and eight Subject Area Groups have formulated their Reference Points and Guidelines. The five Ministries of the five countries have signed a Communiqué indicating their intention to collaborate more closely; a pilot student mobility scheme is soon to start. This article explores the Central Asian experience as an example of the construction of a Higher Education area in Asia, and looks at what the future appears to promise, in terms both of challenges and of positive developments.
\end{abstract}

Keywords: Tuning Process; Central Asian higher education area; Tempus projects; higher education regions; international cooperation.

\section{Introduction}

Efforts at improving education through international cooperation are hardly new. Between the World Wars, in the hopeful times of the League of 
Nations, Europe gave birth to the International Committee on Intellectual Cooperation and the International Bureau of Education, ${ }^{1}$ ancestors or predecessors of UNESCO. UNESCO itself was founded in the aftermath of the Second World War, again with the hope of improving education as a major tool for preventing war; it encouraged cooperation and recognition agreements in world regions, and several of these were signed especially in the 1970s and 1980s (by Latin America and the Caribbean, Africa, Mediterranean and Arab states, as well as in Europe). ${ }^{2}$ Such initiatives represented expressions of good will, and hopes for the future, but as we are well aware today, they were timid and uncertain beginnings with respect to the requirements of higher education in the $21^{\text {st }}$ century.

The hope for peace and well-being of the world's peoples continues to bring to the fore the need for cooperation in higher education, and the possibilities for students and academic staff to be mobile, in the interests of improving international understanding and developing knowledge to the benefit of all. Today the stakes are as high as ever, but the context has changed. Universities are now participating willy-nilly in the globalisation process. Levels of academic mobility are unprecedented, and Higher Education Institutions measure each other on a world scale. Competition as well as collaboration is inevitable. National systems and individual universities want to appear among the best in order to attract students from abroad, or simply to keep their own best students at home rather than allowing them to enrol elsewhere. At the same time, a complex and important process of reform is under way, in which Higher Education has been forced by governments and society to explain more accurately and effectively what it is doing, and to ensure that its offer is actually relevant and needed.

This general process of reorganisation has many protagonists, many beneficiaries, and many strands. It includes developments in learning/ teaching and assessment (the shift to the learner-centred paradigm), in governance, in quality assurance and enhancement. It pressures HEIs to coordinate their systems and to work together at regional or macro-regional

1 The UNESCO Archive entry for the International Committee on Intellectual Cooperation (ICIC) describes its purposes and its actual modes of operation: http://biblio-archive.unog.ch/ Detail.aspx?ID=408. The International Bureau of Education (IBE) has been a part of UNESCO, with intellectual and functional autonomy, since 1969: http://www.ibe.unesco.org/ en/about-the-ibe/who-we-are/history.html.

${ }^{2}$ Fernando Miguel Galán-Palomares and Kevin Guillaume, Europe at the Global Edge, articulating the global dimension of EHEA through recognition, presentation 25 November 2014, Bucharest, Bologna Process Researchers Conference, forthcoming (at present available at http://fohe-bprc.forhe.ro/papers/). 
level. In this process, Tuning ${ }^{3}$ and the Bologna Process ${ }^{4}$ have had key roles, as pioneers and as models. Here we examine how such developments are interpreted in Central Asia, with particular reference to the TuCAHEA ("Tuning Central Asia") project. ${ }^{5}$

\section{Tuning and the development of Macro-regions in HE}

The beginnings of Tuning, in parallel with those of the Bologna Process, involved Europe, indeed only the western part of what is now the European Union. The reasons were many: although it had very recently (1999) become possible to include central and eastern European countries in Erasmus projects, the sheer scale of the initial Tuning Project was daunting. Even limiting it to Western Europe, the financial and organizational challenge was immense. With officially five, but in practice seven, pilot Subject Area Groups, 14 member countries, and a methodology still to be invented, "Tuning Educational Structures in Europe" took the first steps toward providing tools for the practical and positive implementation of student centred learning on a regional scale. European Tuning was subsequently extended to include (in some Subject Areas) the central and eastern European countries which were then preparing for entry into the European Union. The Erasmus Thematic Networks, which by definition had members in all eligible countries, were also asked to 'tune', so that the European Tuning world came to embrace all the countries admitted to Erasmus at that time. The model and the methodology were created in what today we can understand were unusually challenging conditions: in Europe each country had its own strong cultural, academic and linguistic traditions, often conceived in opposition to those of its neighbouring countries. Cooperation, and agreement on such

${ }^{3}$ On Tuning as a worldwide process, a good starting point is the Tuning Educational Structures in Europe website (http://www .unideusto.org/tuningeu/), which provides links to the Tuning projects in Europe and in other countries and continents, and allows access to all publications.

${ }^{4}$ Most of the basic information on the Bologna Process can be accessed through the website of the European Higher Education Area (EHEA): (http://www.ehea.info/) which, in addition to information on current activities, also provides links to information on the earlier phases of the Bologna Process.

5 "TuCAHEA. Towards a Central Asian Higher Education Area: Tuning Structures and Building Quality Culture" is a Structural Measures Project (2012-2015) supported by the European Commission through DG EAC, Tempus Programme (Project 530786-TEMPUS-12012-1-NL-TEMPUS-SMHES) Grant Agreement: 2012-3025. The website in English and Russian can be found at www.tucahea.org. 
sensitive matters as the competences to be formed in higher education, was truly difficult, truly needed, and, amazingly, successful. ${ }^{6}$

Other European 'tunings' were carried out subsequently in single countries: in the Russian Federation, in Georgia, and in Lithuania for example. In each case they contributed new and important insights. However the multi-country model by its very nature proved more incisive, more difficult, and also more innovative. Tuning showed the effectiveness of its approach in particular at a regional level. ${ }^{7}$

The second great regional initiative was Tuning Latin America. In this case, as is well known, 18 countries of South and Central America joined together to tune 12 Subject Areas, involving several hundred institutions, and - very importantly - the eighteen Ministries. It was the first time in history that these countries were able to cooperate on this scale in the field of higher education. Today the successes of Tuning Latin America are before the eyes of all, and the milestones reached in terms of regional cohesion and cooperation in higher education are truly remarkable. At the outset, the difficulties seemed overwhelming, because of the social and political disparities between the countries. And yet, in some significant ways, Tuning Latin America was less challenging than Tuning Europe, because of the shared language and similar roots of the Latin American HEI models. ${ }^{8}$

As in Europe, the factor that allowed the success of Tuning Latin America was the natural curiosity and desire to collaborate of academics working in the same Subject Areas, but in systems which were not able to communicate easily because of their diverging cultural and political histories. Although academia has often supported nationalism and conflict, Tuning showed decisively that academics and academic authorities were ready and able to cooperate on a regional scale when offered cogent reasons for doing so and a carefully organised platform which could guide them step by step to reach their objectives.

The successful European and Latin American models, the former accompanied by the important developments in the Bologna Process, naturally drew the interest of other countries and regions. Very large countries, such as the United States of America, China and the Russian

${ }^{6}$ Tuning Educational Structures in Europe, Final Report. Pilot Project - Phase I (Bilbao and Groningen: University of Deusto Press, 2003).

${ }^{7}$ For Tuning in Georgia: http://tuningacademy.org/tuning-georgia/?lang=en; for Lithuania: http://tuningacademy.org/tuning-lithuania/?lang=en; for Russia, see below, n. 9.

${ }^{8}$ From the general Tuning Latin America website (http://www.tuningal.org/) one can access links to all information and publications relating to both the first and the second phases of the project (2004-2007 and 2011-2013). 
Federation, have chosen to 'tune' by themselves, albeit observing and taking inspiration from the European and Latin American projects. ${ }^{9}$

Most remarkable is the truly macro-regional Tuning Africa. Because of the sheer size of the continent, with its more than 54 countries, its territory of more than 30 million $\mathrm{km}^{2}$, and its 1.1 billion people - not to speak of its great political, cultural, economic and climatic differences - Tuning Africa was organised in its first phase by attributing the responsibility for one large sector (Medicine, Teacher Education, Agriculture, Mechanical Engineering, and Civil Engineering) to a sub-region (Northern, Southern, Western, Central, and Eastern Africa respectively), although HEIs were allowed to participate in SAGs in other regions. ${ }^{10}$ Certainly such a project as Tuning Africa could be conceived of and implemented because of the examples and the experience of the previous macro-regional projects.

\section{Central Asia, a macro-region?}

Tuning has developed remarkable experience in organising initiatives which contribute in a substantial way to developing cooperation and excellence in macro-regions, which typically have coincided with continents.

Continents, however - geographers and historians tell us - are constructed realities rather than certain and obvious divisions of the landmasses of the globe. ${ }^{11}$ In no case is this more evident than that of the large Eurasian mega-continent with its many possible subdivisions. Is Europe distinct from Asia? Or vice versa? There are many who would prefer to consider that Europe, wherever it begins or ends, and Asia form one large continent, Eurasia, and that the inner divisions are simply misleading. Today one may hear references to 'the Americas' (which? North, South, Central? Latin America or North America - with or without Mexico?), to North Africa, Sub-Saharan Africa, Central, Eastern or Western Africa and so forth. In the case of the various parts of "Eurasia", we may speak of Europe (Eastern, Western, Southern, Northern, Central, Baltic, Balkan) - and then there are the Far East, the Near East, the Middle East (East being understood from a European point of view), the Indian 'sub-continent', South East Asia and so forth. Each of which has possible aspects of ambivalence and overlap.

\footnotetext{
${ }^{9}$ For the USA: http://tuningusa.org/; for China: http://tuningchina.org/; for Russia: http:// tuningrussia.org/.

${ }^{10}$ For Tuning Africa, see the information and publications on http://www.tuningafrica.org/.

11 Martin W. Lewis and Kären E. Wigen, The Myth of Continents. A Critique of Metageography (Berkeley and Los Angeles: University of California Press, 1997).
} 
Last but not least, there is 'Central Asia' - also known as Middle or Inner Asia. ${ }^{12}$ Here too, the opportunities for confusion, ambivalence and overlap are numerous. Which countries or territories exactly does it comprise? Today there are a number of competing definitions, from the very inclusive to the very restricted. Under the USSR, on the one hand, Central Asia was considered to consist of Tajikistan, Turkmenistan, Uzbekistan and Kyrgyzstan. Subsequently, by agreement of the rulers of the new republics that emerged in the early 1990s, Kazakhstan, territorially larger than any of the other four, was added to the new grouping. On the other hand, very inclusive definitions (such as that of UNESCO) link up with the five republics the western territories of the present Peoples' Republic of China (Xinjiang), Mongolia, Tibet, parts of Russian Siberia, with territories including Pakistan, Afghanistan, not to mention parts of Iran and India. ${ }^{13}$

The reason for such uncertainty, or variety of understandings, is easy to comprehend. Central Asia, whether in a larger or smaller version, is located at the 'core' or the heart of the entire continent, and historically has been connected tightly with all the bordering and outlying regions. Iranian, Turkic and Mongolian peoples have been the most in evidence in the rich and varied history of the region; sometimes conquered from the outside, more often conquering, and often assimilating into the neighbouring regions. Central Asia in the vast extension of its steppes, forests, deserts and high mountains has generated such empires as Timurid or Mughal India, or Yuan China. It has also experienced times of political division, such as that in the $19^{\text {th }}$ century which made possible the Russian conquest of 'Turkestan' as an outcome of the struggle with the British Empire that goes under the name of the 'Great Game'.

Present-day Central Asia still constitutes an object of interest for various outside actors, and in its turn looks toward the rest of the world for economic and political partners, as well as for collaboration in higher education. In the

12 There is a vast bibliography on Central Asia, its history and present day society: useful overviews where maps and other references may be found are, e.g., Svat Soucek, A History of Inner Asia (Cambridge: Cambridge University Press, 2000 [2006, $7^{\text {th }}$ printing]); Rafis Abazov, Palgrave Concise Historical Atlas of Central Asia (New York: Palgrave Macmillan, 2008); Peter B. Golden, Central Asia in World History (Oxford: Oxford University Press, 2011). An illuminating comparative study is Alexander Morrison, Russian Rule in Samarkand 18681910: A Comparison with British India (Oxford: Oxford University Press, 2008).

${ }_{13}$ UNESCO's 6 volume History of Civilizations of Central Asia, including volume VI which covers the area until very recent times (Towards the contemporary period: from the midnineteenth to the end of the twentieth century [Paris: UNESCO Publishing, 2005]), uses the broadest criteria. Instead, for the United Nations in its Composition of macro geographical (continental) regions, geographical sub-regions, and selected economic and other groupings (http://www.cnbc.com/id/102166864) the region comprises the standard five republics. 
context of the attempt we describe here to build a CAHEA (a Central Asian Higher Education Area), this geopolitical and cultural reality cannot be forgotten. The Muslim Turkic speaking population of Xinjiang (Xinjiang Uyghur Autonomous Region) borders on Kazakhstan, Kyrgyzstan and Tajikistan (as well as Mongolia, Russia, India, Afghanistan and Pakistan), and is the seat of ethnic conflict, as the Han Chinese population increases. China is currently investing great sums in building infrastructure in the neighbouring republics, and has very recently announced its strategic objective of realizing important new commercial and political bonds in the framework of its 'Silk Road' project. ${ }^{14}$

The Russian Federation also sees itself, rightly, as strongly connected with the five Central Asian republics which identify themselves as today's Central Asia. The Confederation of Independent States (the Russian 'Commonwealth' initially formed by the Russia Federation, Ukraine and Belarus), was joined almost immediately by all of the present five, along with Azerbaijan, Armenia and Moldova. Subsequently the "CIS" confederation has continued to exist, supported with varying degrees of conviction by most of the rulers of the Central Asian countries and Moscow, although their paths have diverged to varying degrees in recent years. The indisputable fact is that all five emerged from the Soviet decades with a number of features in common, including a Russian speaking and a Russian educated elite, and the nearly universal use of Russian as the language of academia and government. Citizens of Kazakhstan, Kyrgyzstan, Tajikistan and Uzbekistan may travel to Russia without needing a visa; only the citizens of Turkmenistan, which follows a policy of 'permanent neutrality' - understandable considering that it is located between Kazakhstan, Uzbekistan, Iran and Afghanistan - require a Russian visa, and indeed are allowed entry without a visa by no major country except Turkey. ${ }^{15}$

The five Central Asian countries now engaged in working towards a CAHEA are united by a number of important factors. These include periods of shared history, of which the most relevant at present are the most recent - the

${ }^{14}$ China's President Xi Jinping announced an investment of 40 billion US dollars in the "New Silk Road" on 8 November 2014 (see, e.g., http://news.xinhuanet.com/english/ china/2014-11/08/c_133774993.htm); on 10 December the first train from China arrived in Madrid. "The Guardian": http://www.theguardian.com/business/2014/dec/10/silk-railwayfreight-train-from-china-pulls-into-madrid).

15 The United Nations, with the resolution of its General Assembly $\left(90^{\text {th }}\right.$ plenary meeting, 12 December 1995, A/RES/50/80 of 11 January 1996), recognized the status of permanent neutrality declared by Turkmenistan and called upon its members to respect that status as well as the "independence, sovereignty and territorial integrity" of that country (http://www.un.org/ en/ga/search/view_doc.asp?symbol=A/RES/50/80\&Lang=E) Turkmenistan celebrates 12 December each year as Neutrality Day. 
inclusion in the Russian Empire and the common experience as part of the Soviet 'Imperium'; the shared Russian language as a lingua franca not only within the elites, the common origin of the present HE system in the Soviet system, and the common perception of being subject to many of the same pressures and tempted by many of the same opportunities, as represented by foreign investment, and the policies of Russia, China, the United States and the European Union. They share their Islamic heritage. There are also striking similarities from a demographic point of view: the population pyramids of all five countries look very different from those of European countries: they show very young populations, with strikingly numerous age groups from 15 to 29 , a marked contraction in the immediately younger age groups (5 to 14 ) and a very vigorous expansion in the numbers of those aged 0 to $4 .{ }^{16}$

And then there are differences: in territorial extension, in overall population, in self-image, in prosperity, in language, and in bonds with other countries. In territorial extension, Kazakhstan is much the largest, stretching from Mongolia to the Caspian Sea, counting nearly $3,000,000 \mathrm{~km}^{2}$, whereas Uzbekistan and Turkmenistan each have slightly under $500,000 \mathrm{~km}^{2}$, largely desert; and Kyrgyzstan and Tajikistan respectively close to $200,000 \mathrm{~km}^{2}$ and $143,000 \mathrm{~km}^{2}$, mostly very high mountains. The most populous by far is Uzbekistan, with close to 30 million inhabitants, whereas Kazakhstan counts 18 million, Tajikistan 8 million, Turkmenistan 5 million and Kyrgyzstan nearly 6 million inhabitants. ${ }^{17}$ In all countries most of the Russian population has left, whereas there are significant mixtures of ethnic and linguistic groups, notably Tajiks in Uzbekistan, and smaller numbers of the various peoples in each of the neighbouring countries. Most importantly, the 'national' languages of four of the five countries belong to the Turkic family, whereas that of Tajikistan is a neo-Persian language, akin to those spoken in Iran, much of Afghanistan and some of Pakistan and India. Nominal GDP per capita ranges from around $\$ 1000$ US in Tajikistan and Kyrgyzstan to more than $\$ 13,000 \mathrm{US}$ in Kazakhstan. ${ }^{18}$ All are presidential republics.

Central Asia over the millennia has typically included both sedentary urbanised and mercantile populations and more mobile nomadic populations. Until modern times the prosperity of area was due to its very advanced

${ }^{16}$ United States Census Bureau, International Data Base: https://www.census.gov/ population/international/data/idb/informationGateway.php, search by country for Mid-year Population by Five Year Age Groups and Sex.

${ }_{17}$ Central Intelligence Agency (CIA). The World Factbook (https://www .cia.gov/library/ publications/the-world-factbook/index.html).

18 World Bank figures for 2013 (http://data.worldbank.org/indicator/NY.GDP.PCAP. CD). 
agriculture, and the production and trade along the Silk Road. Settlements were often ethnically and linguistically mixed, or alternatively different villages in a single region were formed of peoples of different languages and cultures. With the advent of the post-Soviet national republics, each with a titular 'people', language and culture, governments have encouraged the construction of national diversity, creating national heroes and emphasizing certain aspects of past history.

Periodically efforts have been made, with greater or lesser resolve and success, to replace Russian as the language of instruction with the titular national languages. Efforts have been made to 'cleanse' the national language of borrowed words, and a leit motif over the last century has been oscillation as to whether the national languages should be written using Latin or Cyrillic characters. Today both can be found in Uzbekistan for example, where the younger generations tend to know Russian much less well than their elders, and where the Uzbek language is widely used in University settings as well as in ordinary life. In Turkmenistan all higher education is carried out in Turkmen, whereas in the other countries Russian is used along with the 'national' language. The younger generations increasingly study English as well.

Certainly linguistic issues create one of the challenges for building a higher education area, in that replacing the common vehicular language with national languages or English complicates regional cooperation and mobility. Even more complicated challenges derive from the ups and downs of political relations between the countries themselves and their governments. During the more than two decades since the break-up of the Soviet Union, there have been armed conflicts and incidents, including a war between Tajikistan and Uzbekistan, border tensions between Kyrgyzstan and Uzbekistan and so forth. The borders between the countries were designed to make it difficult to unite them, as part first of a Russian and then of a Soviet effort to weaken larger pan-Islamic or pan-Turkic alternatives. ${ }^{19}$

In all five countries, the Higher Education systems are highly centralised under the authority of Ministries, typically of Education and Science, and changes in Higher Education institutions and systems require the support of ministerial personnel at many levels. Academic staff are the object of much attention, including, for example, being asked by their Ministry to attend

${ }^{19}$ On the political debates and the decision to emphasize or even create national divisions in Central Asia (or Russian Turkestan as it was then known) at the time of the Russian Empire, and above all under the Soviet Union, see Olivier Roy, The New Central Asia. The Creation of Nations (New York, London: I.B. Tauris, 2000; reprinted in 2007 with the title The New Central Asia. The Birth of Nations; French original: La Nouvelle Asie centrale ou la fabrication des nations (Paris: Editions du Seuil, 1997). 
centrally organised courses to keep their knowledge of the subject matter up to date. Rectors are appointed by central authorities, and often convened to meetings in the capital cities. Academic authorities are considered so important that they may need special permission for visits abroad. All countries place the education of their citizenry very high among their official priorities. Pressure for or against cooperation with neighbouring countries, in higher education as in other areas, is subject to change in direction and intensity, according the overall political scenario and relations with each of the other countries taken separately.

Central Asia, as a world region, like all world regions, has uncertain borders and its component countries are pulled to varying degrees to make agreements or collaborate with other actors. In this picture, Europe, the EHEA and European Commission programmes play and foreseeably can play a relevant role.

\section{Europe, the European Commission, and the EHEA}

Since the early 1990s, the Central Asian countries have been objects of interest for many countries and organisations - including not only the Russian Federation, but also Turkey, Saudi Arabia, China, Korea, the United States of American, and UNESCO, among others. Agendas have changed with the development of the new republics and the more general political situation, where propinquity to Afghanistan, Iran and China has an obvious influence. As regards higher education, the interventions have been in the direction of encouraging mobility, founding and financing HEIs to support and extend cultural and economic affinities,${ }^{20}$ and also in promoting own HE institutions and systems.

In this general context the European offer of non-invasive nonprescriptive models and assistance in developing HE has had notable success. The European 'soft' proposals have proved attractive and useful for the Central Asian countries. Some Central Asian HEIs chose early on to sign the Magna Charta Universitatum, ${ }^{21}$ and looked with interest at the Bologna

${ }^{20}$ See, for example, the Kazakh-British Technical University, founded in 2000-2001 on the basis of an agreement between the President of Kazakhstan and the British Prime Minister with the support of the British Embassy and the British Council (http://www.kbtu.kz/en/ node/62), and a number of world class actors in the oil and gas field among the sponsors; the Krygyz-Turkey Manas University in Bishkek, founded jointly by the governments of Turkey and Kyrgyzstan by an agreement stipulated in Izmir in 1995. (http://manas.edu.kg/index.php/ manas-university/introduction); the Russian Tajik (Slavic) University in Dushanbe was founded in 1996 by the governments of the two countries $8 \mathrm{http}: / / \mathrm{www} . r t s u . t \mathrm{j} / \mathrm{rtsu} /$ istoriya).

${ }^{21}$ At present 68 Kazakh HEIs are among the signatories; 13 Kyrgyz HEIs; one Turkmen HEI, one Uzbek HEI and no Tajik University (http://www2.magna-charta.org/). 
declaration and the early developments of the Bologna Process. The adhesion of the Russian Federation to the EHEA defused some of the tensions that the countries experienced in being pulled on the one hand toward the higher education policies that Russia wished to extend to the CIS countries, and on the other toward the European system. Some Central Asian Universities have joined EURASHE or the EUA. ${ }^{22}$

An important facilitator of successful higher education reform in Central Asia has been the European Commission through its TEMPUS and TACIS programmes. TACIS promoted "democratization, the rule of law and the transition toward the market economy of the CIS countries"; TEMPUS was the educational arm of that support. TEMPUS (Trans European Cooperation Scheme for Higher Education) was adopted by the Council of Ministers of the European Union in May 1990, and subsequently extended until 2013; its initial mandate was "to stimulate cooperation with the New Independent States and Mongolia (the Partner States) in the restructuring of their higher education systems". It was part of the TACIS Programme, which had the overall remit of fostering "the development of harmonious and prosperous economic and political links between the European Union and these Partner States". 2.

TEMPUS channelled effectively the enthusiasm of many European HEIs for the new possibilities of cooperation with the countries formerly part of the Soviet Union, and the willingness of most of the Central Asian countries to look towards Europe to establish reciprocal relations. ${ }^{24}$

\section{Building a CAHEA}

\section{Beginnings}

The breakup of the Soviet system placed each of the nascent republics in a complicated situation in which cultural reference points as well as political

${ }^{22}$ EURASHE has 3 individual Kazakh member HEIs including the TuCAHEA partner Korkyt Ata Kyzlorda State University; and the EdNet Association, also a TuCAHEA partner, is a full member of EURASHE, representing 37 Kyrgyz HEIs. There are 9 Kazakh members of the EUA.

${ }^{23}$ Tempus Tacis Project Management Handbook, edited byMarek H. Dominiczak (Luxembourg: Office for Official Publications of the European Communities, 1996), available at http://eacea.ec.europa.eu/tempus/doc/tacishandbook_en.pdf.

${ }^{24}$ Róisín McCabe, Philippe Ruffio, and Chiara Tiberi, The Main Achievements of the Tempus Programme in Central Asia 1994-2013 (European Commission, Education, Audiovisual and Culture Executive Agency, Brussels, 2014), available in pdf format in English and Russian at http://eacea.ec.europa.eu/tempus/tools/publications_en.php\#1. 
and economic structures and practices needed to be modified radically and rapidly, notwithstanding the economic meltdown. On the one hand, the consolidated scholastic and higher education systems bequeathed by past generations constituted an important positive patrimony for the young countries, who could count at least on the high existing levels of scholarization; on the other there were strong pressures to develop new national systems, capable of educating future citizens to enter the 'free market' and make their way in the capitalistic world, and such as to encourage identification with their new country.

Simplifying, we may say that the countries first looked to differentiation rather than continuing cooperation. Universities which had been important in Soviet times formed the basis of the new national systems, while new institutions were created to ensure geographic and disciplinary spread. Naturally the academic and scientific elites who had been colleagues in Soviet times, receiving their degrees from institutions in Moscow or Leningrad, looked back to Russian academia with a degree of nostalgia.

In April 2004 an important conference of Central Asian ministers and rectors was held in Almaty, and the invited key note speech was on the prospects of Bologna Process and also provided the opportunity to present Tuning. Already at least some of the main actors had begun to support the idea that something similar could be attempted in Central Asia. ${ }^{25}$

In Kyrgyzstan in particular a project was set up directly under the President of the country to develop new criteria for the curricula in Economics. Two members were chosen from each of a number of key universities from various parts of the country to work together to develop new pilot curricula. Thanks to the then director of the Tempus Office in Bishkek and the EdNet association of Universities, it was possible to work intensively together under the guidance of the author of the present text, at that time member of the Tuning Management and ECTS Counsellor, and to elaborate new competence-based curricula for programmes in Economics, including Accounting and Macroeconomics, taking into account workload measured in terms of student time. The new curricula were immediately applied, first experimentally in selected institutions and then more widely. Tuning-

${ }^{25}$ Ann Katherine Isaacs, "The Bologna Process. A Geography of European Higher Education for the $21^{\text {st }}$ century", Almaty, Alatau, 5 April 2004. The speech presented not only the Bologna Process, but also the achievements at that time of Tuning Educational Structures in Europe, and its extension to the Thematic Networks, the 'Archipelagos' (see http://www. archhumannets.net) and Latin America. There is a brief note about the Conference on the useful website of the "Central Eurasian Studies World Wide" programme (http://cesww.fas.harvard. edu/index.html), maintained by the Davis Center for Russian and Eurasian Studies, Harvard University, p. 16 (see http://cesww.fas.harvard.edu/cel_conf16.html). 
Bologna-ECTS definitions and methodologies began to enter the national academic culture and new expertise and bonds of trust were formed. ${ }^{26}$

In November 2004 a Tempus regional conference on "Higher education in Central Asia: on-going reforms and future perspectives" was organised by the European Commission in Tashkent. The Kyrgyz pilot Tuning and related themes were presented and discussed, ${ }^{27}$ and the conference itself provided an opportunity to look at concrete ways in which Tuning and other tools for higher education reform could be implemented in the Central Asian area. ${ }^{28}$

\section{Bologna.kg: Tuning in the Kyrgyz Republic}

The first Tuning project in Asia was Bologna.kg, a Tempus Structural Measures project carried out in $2005-2006$, followed by a second project, Bologna.kg2 which made it possible to involve more institutions and more Subject Areas. Both were designed and coordinated by the University of Pisa and aimed to build on and develop the accomplishments of the 2004 ad hoc Presidential working group in Economics. In the course of the two projects, 11 subject areas were 'tuned', and the results of the work were published and distributed in various forms by the Bologna information and dissemination centres that were set up not only in Bishkek, the capital, but also in various other regions of the country, including Karakol, Naryn, Osh and Jalalabad and in the final part of the project, Talas. Only the remote Batken province in the end did not have a Bologna.kg centre or partner. The implications of student-centred learning, teaching and assessment were generic competences were presented, debated and officially approved at national level..$^{29}$

${ }^{26}$ See Ann Katherine Isaacs, “An ECTS/'Tuning' -based experiment in curriculum design by Kyrgyz Universities"; Kynatbek Smanaliev and Farida Ryskulueva, "Prospects of Development of the Higher Education in Kyrgyzstan and problems of joining the Bologna Process"; and Chinara Adamkulova, "Influence of the Tempus Programme in the reformation of higher education", all in Proceedings of the Tempus Regional Conference "Higher Education in Central Asia: Ongoing Reforms and Future Perspectives”, Tashkent, 22-23 November 2004, edited by Aziza Abdurakhmanova, Claire Morel, Heather Mowbray, and Shokhida Safarova (available online in English and Russian at http://eacea.ec.europa.eu/ tempus/doc/tashkent_en.pdf, 68-80).

27 Ibid.

28 Proceedings of the Tempus Regional Conference cit., passim.

${ }^{29}$ The first phase of Bologna KG was entitled "Creating National Information Centers about the Bologna Process in the Kyrgyz Republic", and it was a Tempus Structural Measures Project (SCM TO12B04): http://www.bolognakg.net/default2.html. The second phase (Bologna.KG2, http://www.bolognakg.net) "Extending Centres on the Bologna Process and 
More or less at the same time an official Russian Tuning, in Mathematics and European studies, was inaugurated, and a second Tuning related Tempus project, RHUSTE, was implemented under the guidance of the State University of Milan. ${ }^{30}$ The RHUSTE project undertook to tune the Subject Areas of "Culturology" and History and also developed positive synergies with Bologna.kg. A happy circumstance was the fact that Deans of all Russian History Faculties were working together at that time to update their 'standards': they were able to utilise the Tuning methodology proposed by the RHUSTE project to achieve their aims.

The Kyrgyz project used and developed the results of Tuning Education structures in Europe and Tuning Latin America as well as to contributing to them and to Russian Tuning. Its results and findings, along with those of other Tempus projects, were used to inform the reorganization of the higher education sector in the country and led to a request to accede to the EHEA, signing the Bologna Agreements. The request was refused on the basis that Kyrgyzstan had not signed the European Cultural Convention, which it could not do insofar as it was not (and could not be for geographical reasons) considered European, and become a member of the Council of Europe. ${ }^{31}$ The request of the Kyrgyz Minister of Education to attend the up-coming London conference as an observer was rejected by the Bologna Follow-Up Group (BFUG) on the grounds that places were 'very limited', to the distress of those who had worked so hard to develop and implement the reforms. On the positive side, a 'Bologna Policy Forum' was instituted at the next Bologna Ministers' conference, and the Kyrgyz Republic was invited to attend along with the non-European 'heavyweights' (such as the United States, India, China and South Africa). ${ }^{32}$ Subsequently, Kazakhstan was allowed to adhere

supporting Tuning Teams in Kyrgyz Republic", was also a Tempus Structural Measures project (SCM TO57A06-2006).

${ }^{30}$ Tuning Russia, Reference Points for the Design and Delivery of Degree Programmes in Education, edited by Ivan Dyukarev, Arlene Gilpin and Evgeniya Karavaeva (Bilbao: University of Deusto Press, 2009); History and Culturology. Russian Tuning/ECTS-based educational models for the implementation of the Bologna Process in Human Sciences (Cheliabinsk State University: Cheliabinsk 2008), available at http://tuningacademy.org/wp-content/ uploads/2014/02/RHUSTE_Booklet-for-the-Subject-areas-of-History-and-Culturology.pdf.

${ }^{31}$ Letter from Alan Johnson, then UK Secretary of Education and Skills, to the Minister of Education of the Kyrgyz Republic, forwarded to the author on 19 February 2007; for the signatories of the European Cultural Convention: http://conventions.coe.int/Treaty/Commun/ ChercheSig $. \operatorname{asp} ? \mathrm{NT}=018 \& \mathrm{CM}=\& \mathrm{DF}=\& \mathrm{CL}=\mathrm{ENG}$; on the Convention itself: http:// conventions.coe.int/Treaty/Commun/QueVoulezVous.asp?CL=ENG\&NT=018.

32 The First Bologna Policy Forum, which both Kyrgyzstan and Kazakhstan attended, was held in Louvain-la-Neuve, 29 April 2009: http://www.ond.vlaanderen.be/hogeronderwijs/ bologna/forum/. 
to the EHEA and to sign the European Cultural Convention, although it still has not obtained full membership in the Council of Europe - which it was allowed to request because it is recognised that $4 \%$ of its territory is 'European'. It has a special observer status. ${ }^{33}$

\section{The TuCAHEA Project: objectives and achievements to date}

The TuCAHEA project was conceived in 2009 in the context of a Central Asian conference held in Bishkek at Kyrgyz-Turkey Manas University under the auspices of the Kyrgyz National Tempus Office. There, the coordinator and the partners of the Bologna.kg projects were able to discuss ways forward with representatives of the other four countries, including their National Tempus Officers, and begin to elaborate a concrete regional strategy. The project was eventually designed and proposed in spring 2012 as a Tempus Structural Measures Project, coordinated administratively by the University of Groningen (NL) and scientifically by the University of Pisa (IT). The Consortium comprises eight European HEIs, all of which have important Tuning and Bologna experience, including Groningen and Deusto as Joint Coordinators of Tuning. The Central Asian partners, from all five countries, are 33 HEIs, one HE Association, and the five Ministries responsible for Higher Education in the five countries.

TuCAHEA's title is "Towards a Central Asian Higher Education Area: Tuning Structures and Building Quality Culture". The project summary recites as follows:

The broad aim of TuCAHEA is to contribute to building a Central Asian Higher Education Area [CAHEA], aligned with the European Higher Education Area [EHEA], able to take into account and valorise the specific needs and potentials of the Region and of the partner countries, thus responding to the needs of the higher education community and society at large.

The project is organised as a Central Asian [CA] Tuning Process based on the methodology developed worldwide by academics in collaboration with students, graduates, administrators, employers and ministries. TuCAHEA aims to extend the use of competence-based quality tools for planning and delivery of Higher Education [HE] programmes, enhance regional HE

${ }^{33}$ For the decision to allow Kazakhstan to accede to the European Cultural Convention: https://wcd.coe.int/ViewDoc.jsp?Ref=CM/Del/Dec(2010)1074/7.3\&Language=lanEnglish\& Ver=original. As to its observer status in the Council of Europe, see Resolution 1526 of 2006: http://assembly.coe.int/Main.asp?link=/Documents/AdoptedText/ta06/ERES1526.htm. 
systems, create a platform for sharing knowledge and elaborating quality tools across the region and in each country. It encourages legislation to create regional cohesion in alignment with the EHEA, it establishes pilot Tuning Subject Area Groups able to formulate Guidelines and Reference Points for key sectors, it trains ministerial, academic and independent experts in the use of competence-based tools, it fosters student mobility within and outside the region and tests and perfects the quality and recognition tools necessary for mobility; it establishes information/dissemination centres both in capitals and in other areas of the partner countries

The principal outcomes will be to extend knowledge of the worldwide Tuning process, involving the CA Area directly in its broad international context; to enhance knowledge of existing quality and recognition tools as a basis for further elaboration; to carry out broad consultations on both generic and subject specific competences, to produce a number of Tuning Subject Area reports; to produce competence- learning out-comes based descriptions of degree programmes using the Degree Profile template developed by Tuning and the ENIC-NARIC Network, and more generally to creating a basis for a Central Asian Higher Education Area, developing premises for a CA Qualifications Framework and Credit System. ${ }^{34}$

The project is now entering its third year, and has adhered very closely to the original plan. To date it has held four Plenary Conferences and Working Meetings (in Almaty, Bishkek, Dushanbe and Samarkand) and 20 'Country Meetings' of the members of each country, two Study and Training Visits to Europe; it has developed a Central Asian list of Generic Competences; eight Subject area groups (Business and Management, Economics, Education, Engineering, Environmental Protection and Food Safety, History, Language, Law) have elaborated their Subject Specific competence lists, and prepared their Guidelines and Reference points. A very large-scale consultation on the perceived importance and degree of achievement of the competences was carried out in the five countries in 2012, and it yielded 20,463 responses.

In June 2014 TuCAHEA Ministerial representatives of four of the five countries met in Rome under the auspices of the Italian Ministry of Education, Universities and Research, where they signed a Communiqué agreeing to explore the possibilities for closer collaboration in the Higher Education sphere

${ }^{34}$ The summary appears in English and Russian on the project website, http://www. tucahea.org. For an overview of the project, its objectives and its accomplishments at the end of the first year, see Ann Katherine Isaacs, TuCAHEA: A Regional Strutural Tempus Project for creating a Central Asian Higher Education Area and contributing to the worldwide "Tuning Process", in National Tempus Office in Uzbekistan ed., Tempus IV in Uzbekistan, Tashkent 2013, 293-303. In the same section there are other articles in Russian on TuCAHEA by Dilshadbek Nurmatov , Karligash Umatova and Pulatkhon Lutfullayev, Ibid., 303-320. 
and to facilitate the TuCAHEA pilot regional student mobility scheme. ${ }^{35}$ The Communiqué was later signed by the representative of the fifth country as well. These developments are most encouraging, and are the result of a lively and on-going process of collaboration and debate. Each step has required efforts on the part of all the participants to understand the systems and concerns of the others, and to explain and clarify their own points of view. This is the essence of Tuning, and the experts formed in the TuCAHEA project, many of whom are HEREs (Higher Education Reform experts, formerly in the Tempus context, now in that of Erasmus +$)^{36}$ are well positioned to use the results of the project and to build on them in the Central Asian and broader contexts.

\section{The future of the TuCAHEA project}

In its final year TuCAHEA has a broad path before it. The obstacles are many, but its supporters are proactive and motivated to travel along it as far and fast as possible. The eight SAGs are perfecting the Russian and English versions of their Reference Points and Guidelines so that they can be published in various formats in the spring of 2015. The regional pilot student mobility scheme is about to take off: the selection of the students has already been made and the students will soon begin their studies in host Central Asian country different from their own. Their institutions are using adapted Inter-institutional Agreements and Learning Agreements modelled on those in use in Erasmus+. The Ministerial working group has prepared a 'roadmap' to guide the elaboration of a development of the Communiqué in the direction of a stronger and more ambitious agreement at Ministerial Level. The Ministries have declared their intention to disseminate the TuCAHEA Reference Points among all the HEIs of their countries. They have also asked TuCAHEA to make a full report on the regional student mobility scheme, including descriptions of both the difficulties encountered and the solutions found, with a view to encouraging Central Asian HEIs to promote mobility within the region and not only outside of it. ${ }^{37}$

The foundations have been laid for creating a Credit Reference system, in order to allow the member countries not to change their current systems,

${ }^{35}$ The representative of the Turkmen Ministry was not able to get to Rome in time, and signed later. See http://www.tucahea.org/news/study_trainig.html.

${ }^{36}$ On the Network of Higher Education Reform Experts, their activities and profile, see http://eacea.ec.europa.eu/tempus/programme/heres_en.php.

37 Ingrid van der Meer and Ann Katherine Isaacs, Minutes of the Fourth TuCAHEA Plenary Conference and Working Meeting (Samarkand, 14-15 November 2014), unpublished. 
but rather to identify a standard measurement to which those systems can connect. The proposal at present is to use a 60 credit standard, which would of course facilitate transparency with respect to ECTS in Europe and the Tuning initiated Crédito Latinamericano de Referencia (CLAR). ${ }^{38}$

Relevant steps have also been taken in the direction of creating overarching descriptors for a possible three cycle system aligned with the EHEA. The eight TuCAHEA Subject Area Groups, which include Social Sciences and Humanities as well as Engineering, have developed descriptors for first, second and third levels of Higher Education for their own area, and have begun to think in terms of overarching level descriptors for all disciplines.$^{39} \mathrm{It}$ is premature to imagine that these will be agreed in the very near future; still the fact that tens of academics in the five countries now realise the potential usefulness of defining levels in terms of competences measured in learning outcomes bodes well for a future Central Asian qualifications framework, compatible with but not identical to that of the EHEA.

The future development of TuCAHEA will be defined by the degree of success it achieves in the coming months. Clearly, the overall goal of creating a CAHEA which constitutes a real framework for building excellence in Central Asian HE will require time, tenacity and good luck. Higher education priorities are not normally those that guide Ministers of Foreign Affairs, which is paradoxically is one of the strongest reasons for looking to the realm of higher education to build regional confidence and trust. If conditions permit, the logical continuation would comprise both the 'Tuning' and the normative sides of the TuCAHEA strategy. An obvious step forward would be to 'tune' a certain number of Subject Areas in the sectors which TuCAHEA has not yet addressed, that is principally the Natural, Exact and Healthrelated Sciences. Ministerial input will be fundamental in many ways: in developing competence-based standards and in promoting the use of such tools as Course Catalogues, as well as in supporting and facilitating regional mobility.

\section{UZHELTH and Public Health in Uzbekistan}

The necessity of enlarging the range of TuCAHEA's work to create or to facilitate the creation of a CAHEA was the inspiration for another TEMPUS

38 Tuning Latin America, http://www.tuningal.org/es/publicaciones/cat_view/48publications-in-english-books?start=15.

39 Alessandra Guidi, Shavkat Hasanov, Ann Katherine Isaacs, Minutes of the Joint UZHELTH-TuCAHEA meeting (Samarkand, 15-16 November 2014), unpublished. 
Structural Measures project, now in its second year. ${ }^{40}$ This project has the title "Higher Education Structures to Enhance Public Health Learning and Teaching in the Republic of Uzbekistan" and involves the use of Tuning methodology to create a new holistic and collaborative approach to the various disciplines that bear directly on Public Health, in the most inclusive definition. The UZHELTH consortium has already elaborated Subject Specific competences for Human Medicine, Agriculture, Veterinary Sciences and Environmental Protection and Food Safety. A large-scale consultation has been carried out by the Uzbek partners, which include all the HEIs and Institutes dedicated to the relevant disciplinary areas plus two 'generalist' state universities. The consultation has been carried out in such a way as to allow distinctions between various levels of students and has included in the stakeholder groups consulted separately practicing rural doctors, practicing clinical doctors, patients, parents and care givers amongst others, yielding significant qualitative and quantitative data which is now being analysed.

The UZHELTH project was organised not only for its importance in addressing the Public Health sector in the Republic of Uzbekistan, but also as a pilot initiative for the consolidation and extension of the TuCAHEA strategy. The extreme complexity of broad area addressed made it necessary to begin with one country rather than attempt to involve all five. In fact, the HEIs involved depend on three different Ministries, all of which are full and active partners in the UZHELTH Consortium: the Ministry of Higher and Secondary Specialised Education, the Ministry of Health, and that of Agriculture and Water Resources.

The UZHELTH partners from Uzbekistan recently had the opportunity to participate in the Plenary Conference and Working meeting of the TuCAHEA Consortium held in Samarkand in November 2014. The interacted in several useful ways: the representatives of the Ministries involved in UZHELTH were able to meet with the Ministerial representatives from TuCAHEA; the UZHELTH colleagues contributed to the TuCAHEA

${ }^{40}$ The project summary may be accessed at http://www.uzhelth.org. UZHELTH is a Tempus Structural Measures project. Several articles illustrating its achievements and contribution to Tuning can be found in

Tempus: 20 years of programme activities in Uzbekistan, Erasmus+ Office in Uzbekistan ed.,Tashkent 2014.http://tempus.uz/download/19.12.2014_tempus_20_years_of_programme_ activities_in_uzbekistan.pdf.

Including: Francesco Fornai, "The UZHELTH Experience: exploring communalities and differences in Tuning Public Health related disciplines in Uzbekistan", and Ann Katherine Isaacs, "The Uzbek Contribution to Tuning Central Asia: the TuCAHEA Tempus Project for Creating a Central Asian Higher Education Area and the UZHELTH Project for Public Health in Uzbekistan", respectively: 168-175 and 161-167. 
Environmental and Food Safety SAG which was finalising the English and Russian texts of their Guidelines and Reference Points. Thanks to the reciprocal 'inter-project coaching' the UZHELTH colleagues now have inside knowledge of how Tuning Guidelines are elaborated and how other activities, such as regional student mobility, can be organised. ${ }^{41}$

\section{From Tempus to Erasmus+}

Although the Erasmus+ era began on 1 January 2014, the calls regarding the countries now called "Partner Countries" (which means, curiously, all those that are not "Programme Countries": EU and EFTA member states plus Turkey and the ex-Yugoslav Republic of Macedonia) were published on 8 October 2014..$^{42}$ The prospects for European support of the CAHEA countries in Erasmus+ can be quickly summarised, and they are promising. Bilateral inter-institutional mobility of staff and students between Programme and Partner countries is now possible; cooperation projects between Programme and Partner countries now go under the name of 'Capacity Building', and are foreseen as part of the Erasmus+ Key Action 2.The model is very familiar to those operating in the ex-Tempus countries, including Central Asia: the Tempus model, because of its success, has been extended to the rest of the world. The new Capacity Building projects can be - as Tempus projects were - either Joint or Structural Projects (involving systemic reform and requiring the support of the relevant Ministries, such as TuCAHEA and UZHELTH). Projects again can be national or regional, opening the door to coordinated projects developing different facets of Higher Education reform. ${ }^{43}$

The opportunities for contributing to the consolidation of the CAHEA are many and various aspects of potentialities of the new Programme now must be explored, and coordinated with the new format for mobility.

\section{The CAHEA: Challenges and Prospects}

The idea of creating a Central Asian Higher Education Area, which seemed entirely unrealistic and impractical only a few years ago, is now

${ }^{41}$ Minutes of the Joint TuCAHEA-UZHELTH Meeting, cit. above, n. 39.

${ }^{42}$ European Commission, Erasmus+ Programme Guide, Version 3 (2015): 14/11/2014 (http://ec.europa.eu/programmes/erasmus-plus/documents/erasmus-plus-programme-guide_ en.pdf).

${ }^{43}$ Ibid., 35-50, 145-165. 
entertained seriously by a relevant number of people and institutions in the countries concerned, including people of authority in ministries, rectors, academics and even students. Since achieving that goal depends on coordinated multi-level actions of several types, the possible obstacles and difficulties are numerous.

In fact, the experience of the EHEA and of Tuning in Europe, which provides much of the model for TuCAHEA, has shown itself to be a gamechanging development on a world scale. But, at the same time, 15 years after the Bologna agreements - and not considering the previous decade or more of concentrated work that had prepared the terrain for those agreements - it is clear that much remains to be done to make the vision of the EHEA correspond to reality. The central intuition that Ministries and normative structures would have to change in compatible directions in order to make communication possible between the very different European higher education systems already at the time was recognised as being necessary, but not sufficient. The 'common architecture' would not be enough, which is the reason that Tuning project was designed and began its work at subject area level. Today we are aware that however remarkable achievements have been, there are gaps between what we know can and should be done to build a coherent Higher Education Area and what has actually been accomplished. Awareness is growing that top-down, or even 'middle-down' approaches are not sufficient. For a learner-centred approach to yield all its benefits, teaching staff and students as well as ministerial and academic experts need to understand and contribute more effectively to implementing the new approaches in specific situations and according to specific and verifiable needs. The framework has been elaborated and in many cases applied, as have been many powerful tools; what is still needed is to complete the planned structural changes in all countries, and for the real stakeholders and practitioners - students and academics - to understand better the potential benefits of the changes in progress, and access them.

In Central Asia, as we have illustrated and discussed above, the process of agreement on basic structures or the search for compatibility of cycles or workload measurements has begun. The formulation of level descriptors, applicable to a possible Central Asian Overarching Framework has begun to be discussed. The building blocks for such a development are being put into place through the elaboration and publication, now in progress, of Guidelines and Reference Points for a significant number of key subject areas. Academic and ministerial personnel in all five countries have not only been 'trained', but more to the point, have actually participated in the activities leading to those accomplishments, and hence will be able to extend their activities to other fields and share their knowledge and experience with others. 
Still, as is obvious, each step taken is the result of efforts which in final analysis are dependent on single individuals' commitment, willingness, and ability to participate in the general project - which for a variety of legitimate reasons, of work, family, career, health and so forth, may not continue indefinitely. Many of the necessary normative changes still must be undertaken, and although Ministries now express their desire to address them, clearly each system - just as was the case in Europe - has its own logic and its own rules, which are not given up lightly. As we have mentioned above, relationships between the countries themselves are not stable, but follow political logics not centred on higher education. If anything, cooperation in higher education is seen as a possible way of bring the five countries closer together, at least in the long term.

We may point to a number of areas in which certain basic questions will need to be addressed. For example, Kazakhstan is a full member of the EHEA, and is the only one of the countries concerned that has been allowed to sign the Bologna agreements. It held the co-presidency of the EHEA in the first semester of the current year (2014) during the Greek presidency of the European Union. ${ }^{44}$ Does this mean that Kazakhstan's inclusion in the EHEA will make it necessary for the other countries to follow the lines of the EHEA in order to build a CAHEA that includes Kazakhstan? Kazakhstan is by far the richest country at present among the CAHEA countries, and tends quite naturally to present itself as leader of the region, an attitude not always accepted by the other countries. It is also the case that many young people from the other countries, including the highly educated, emigrate to Kazakhstan to find work. On the one hand, this factor can push toward a greater integration of the higher education sector; on the other, it strengthens the influence of the Kazakh interpretation of the Bologna Process.

Pertinent to our question about whether Kazakhstan will inevitably have a dominant position in the projected CAHEA, it is worth considering that in many ways - as we have seen - the Kyrgyz republic has pioneered 'Tuning', and also the correct application of ECTS, whereas Kazakhstan is using a 'coefficient' system not compatible with ECTS. Although the Kyrgyz request to sign the Bologna agreements as an 'outside' or associated partner was turned down at the time of the London conference, not only had it already implemented a number of 'Bologna' reforms at that time, but it has continued to develop and apply standards for higher education based on competences. Both Kyrgyzstan and Tajikistan are engaged in extending ECTS, using it correctly as a measure of student work load, although not in

\footnotetext{
${ }^{44}$ http://www.ehea.info/article-details.aspx?ArticleId=8.
} 
all HEIs. Uzbekistan, with its nearly 30 million inhabitants and its 72 HEIs, has its own well consolidated system, and can look with interest at the opportunities for closer cooperation, without necessarily abandoning its specific solutions. For example, today the country does not use a credit system, however its 'rating' system of the parameters for the various degree programmes offered, are in reality based on student workload measured in time, and hence can be easily related to ECTS. The Turkmen system ${ }^{45}$ which today has one long undergraduate cycle (5 years except for Medicine which has six) followed by a possible Candidate of Science and Doctor of Science levels, has no credit system, although certainly - as was done in Europe in the $1990 \mathrm{~s}$ - it is possible to relate existing workload to other systems using a credit reference system.

This variety of situations and differing degrees of compliance with the existing rules of the EHEA suggest that the optimal way forward is to 'align' the future CAHEA with Bologna, but to implement a specific Central Asian Tuning as the proper way to ensure that it responds to specific needs and understandings of the countries in question. This seems to be the only realistic way to develop real ownership at all levels, a crucial feature in the Tuning philosophy.

A further question which must be addressed in the future is the relationship between learning/teaching and research, not only in the context of the Bologna third or doctoral cycle, but also more generally with respect to the role of research in HE and in Central Asian HEIs. As is or was the case to varying degrees in several European systems, in the Soviet Union there was a strong distinction between Universities as places where teaching takes place and the Academies of Science (or Culture, and so forth) which are by statute the research institutions par excellence. This binary system differs from the Humboldtian idea that many other countries have followed, according to which the Universities themselves are the places where both basic and applied research is supposed to take place, and students are expected to be involved in research directly. From a Tuning point of view, it is very reasonable that research and learning/teaching go hand in hand, and that learners from the beginning of their higher education experience be brought into direct contact with 'real-world' research. This is seen as one of the most effective way to form and enhance the qualities of curiosity, creativeness, critical thinking, inventiveness that are essential not only in

${ }^{45}$ European Commission, Higher Education in Turkmenistan, updated to July 2012: http://eacea.ec.europa.eu/tempus/participating_countries/reviews/Turkmenistan.pdf.

On the EACEA website, one can find similar studies on the higher education systems of all Tempus countries: http://eacea.ec.europa.eu/tempus/participating_countries/. 
research but in all professions. At present the question of increasing the research functions of Central Asian HEIs is on the agenda; rectors worry about such parameters as the percentage of "PhDs" that they have on their staff. At the same time, the long two tier doctoral studies which were the rule in the Soviet system (with their Candidate of Science and Doctor of Science phases), are being dismantled in some countries, in order to align with Bologna, whereas in others - not only in Central Asia - the double tier system remains. TuCAHEA/Tuning reference points have been developed for the third cycle as well; it will be important to implement the substance of Tuning's insights into doctoral studies rather than (or at least, as well as) focussing on such indicators as the percentage of $\mathrm{PhDs}$.

\section{Concluding Remarks}

Central Asia, as defined in TuCAHEA, is territorially nearly as large as the entire European Union. Its population, however, is very slightly greater than that of Italy. This datum by itself is enough to remind us of the low overall density of population, the large areas where the economy is still prevalently rural or pastoral, and the great expanses of desert or mountainous territories. At the same time, there are many cities, both large and smaller, where major state universities as well as regional universities are located. The population structure implies that there may soon be a relevant contraction in HE student numbers. After a very few years however the age cohorts interested in higher education should return at least to present levels.

The structures and the advances which have been built up and achieved in the meantime, through Bologna.kg, TuCAHEA, UZHELTH and related initiatives, as well as through the investments in time, money and expertise developed individually and thanks to the interest and support of the countries involved, need to be preserved, consolidated and developed for the coming decades. There may be a 'window of opportunity' in which the higher education resources, the capacity to build new understanding through cooperation and apply it, can make the Central Asian Higher Education Area better recognised, more attractive and more closely connected to other Higher Education Areas developing since the beginning of this century. This is a hope, and a goal, of TuCAHEA, and all those working to build the new Central Asian Higher Education Area. 


\section{Bibliography}

Abazov, Rafis. Palgrave Concise Historical Atlas of Central Asia. (New York: Palgrave Macmillan, 2008)

Adamkulova, Chinara. "Influence of the Tempus Programme in the reformation of higher education", Proceedings of the Tempus Regional Conference "Higher Education in Central Asia: Ongoing Reforms and Future Perspectives”, Tashkent, 22-23 November 2004, Aziza Abdurakhmanova, Claire Morel, Heather Mowbray, and Shokhida Safarova eds. http://eacea.ec.europa.eu/ tempus/doc/tashkent_en.pdf, 68-80

Bologna Process Secretariat. First Bologna Policy Forum, Louvain-la-Neuve, 29 April 2009: http://www.ond.vlaanderen.be/hogeronderwijs/bologna/forum/

Bologna.kg Tempus project (Tuning Kyrgyzstan). http://www.bolognakg.net/ default $2 . \mathrm{html}$

Bologna.kg2 Tempus project (Tuning Kyrgyzstan, phase 2). http://www.bolognakg.net Council of Europe (COE). European Cultural Convention: http://conventions.coe. int/Treaty/Commun/QueVoulezVous.asp?CL=ENG\&NT=018

- European Cultural Convention, Kazakhstan: https://wcd coe.int/ViewDoc. jsp?Ref=CM/Del/Dec(2010)1074/7.3\&Language=lanEnglish\&Ver=original .

- European Cultural Convention, signatories: http://conventions.coe.int/ Treaty/Commun/ChercheSig.asp?NT $=018 \& \mathrm{CM}=\& \mathrm{DF}=\& \mathrm{CL}=\mathrm{ENG}$

- Resolution 1526 of 2006: http://assembly.coe.int/Main.asp?link=/ Documents/AdoptedText/ta06/ERES1526.htm

Erasmus Archipelago of Human and Social Arts and Sciences (HUMAN PLUS). http://www .archhumannets.net

European Commission. Erasmus+ Programme Guide 2015, version 3 (2015): 14/11/2014 http://ec.europa.eu/programmes/erasmus-plus/documents/erasmusplus-programme-guide_en.pdf

- Higher Education in Participating Countries: http://eacea.ec.europa.eu/ tempus/participating_countries/

- Higher Education in Turkmenistan, updated to July 2012: http://eacea.ec. europa.eu/tempus/participating_countries/reviews/Turkmenistan.pdf.

- Education, Audiovisual and Culture Executive Agency (EACEA), Network of Higher Education Reform Experts: http://eacea.ec.europa.eu/tempus/ programme/heres_en.php

European Communities. Tempus Tacis Project Management Handbook, Marek H. Dominiczak ed. (Luxembourg: Office for Official Publications of the European Communities, 1996), http://eacea.ec.europa.eu/tempus/doc/tacishandbook_ en.pdf

European Higher Education Area (EHEA). http://www .ehea.info/.

- BFUG Chairs and Vice-Chairs. http://www .ehea.info/article-details. aspx?ArticleId=8

Fornai, Francesco. "The UZHELTH Experience: exploring communalities and differences in Tuning Public Health related disciplines in Uzbekistan", Tempus: 
20 years of programme activities in Uzbekistan, Erasmus+ Office in Uzbekistan ed., Tashkent 2014, 168-175. http://tempus.uz/download/19.12.2014_ tempus_20_years_of_programme_activities_in_uzbekistan.pdf

Galán-Palomares, Fernando Miguel, and Kevin Guillaume. Europe at the Global Edge, articulating the global dimension of EHEA through recognition (Bucharest: Bologna Process Researchers Conference 2014, forthcoming, http:// fohe-bprc.forhe.ro/papers/).

Golden, Peter B. Central Asia in World History (Oxford: Oxford University Press, 2011).

Guidi, Alessandra, Shavkat Hasanov, and Ann Katherine Isaacs. Minutes of the Joint UZHELTH-TUCAHEA meeting (Samarkand, 15-16 November 2014), unpublished.

Harvard University, Davis Center for Russian and Eurasian Studies. http://cesww. fas.harvard.edu/index.htm

Isaacs, Ann Katherine, "The Bologna Process. A Geography of European Higher Education for the $21^{\text {st }}$ century". Almaty, Alatau, 5 April 2004. Unpublished.

—. "An ECTS/'Tuning' -based experiment in curriculum design by Kyrgyz Universities", Proceedings of the Tempus Regional Conference "Higher Education in Central Asia: Ongoing Reforms and Future Perspectives”, Tashkent, 22-23 November 2004, Aziza Abdurakhmanova, Claire Morel, Heather Mowbray, and Shokhida Safarova eds. http://eacea.ec.europa.eu/ tempus/doc/tashkent_en.pdf, 68-80

— .TuCAHEA: A Regional Structural Tempus Project for creating a Central Asian Higher Education Area and contributing to the worldwide "Tuning Process". Tempus IV in Uzbekistan 2013, National Tempus Office in Uzbekistan ed., Tashkent 2013, 293-303. http://www .erasmusplus.uz/files/downloads/ book_tempus_iv_2013.pdf

. "The Uzbek Contribution to Tuning Central Asia: the TuCAHEA Tempus Project for Creating a Central Asian Higher Education Area and the UZHELTH Project for Public Health in Uzbekistan". Tempus: 20 years of programme activities in Uzbekistan, Erasmus+ Office in Uzbekistan ed., Tashkent 2014, 161-167. http://tempus.uz/download/19.12.2014_tempus_20_years_of_ programme_activities_in_uzbekistan.pdf

Kazakh-British Technical University. http://www.kbtu.kz/en/node/62

Krygyz-Turkey Manas University. http://manas.edu.kg/index.php/manas-university/ introduction.

Lewis, Martin W., and Kären E. Wigen. The Myth of Continents. A Critique of Metageography. (Berkeley and Los Angeles: University of California Press, 1997).

Lutfullayev, Pulatkhon. “ТuСАНЕА лойихасшнинг Ўзбекистон олий таълимида халқаро хамкорликни ривожлантиришдаги ахамияти”, Tempus IV in Uzbekistan 2013, National Tempus Office in Uzbekistan ed., Tashkent 2013, 314320. http://www.erasmusplus.uz/files/downloads/book_tempus_iv_2013.pdf

Magna Charta Universitatum. http://www2.magna-charta.org/ 
McCabe, Róisín, Philippe Ruffio, and Chiara Tiberi. The Main Achievements of the Tempus Programme in Central Asia 1994-2013 (Brussels: European Commission, Education, Audiovisual and Culture Executive Agency, 2014). http://eacea.ec.europa.eu/tempus/tools/publications_en.php\#1

Morrison, Alexander. Russian Rule in Samarkand 1868-1910: A Comparison with British India (Oxford: Oxford University Press, 2008).

Nurmatov, Dilshadbek. "Проект TuCAHЕА как инструмент формирования культуры качества в системе высшего образовани в Центральной Азии”, Tempus IV in Uzbekistan 2013, National Tempus Office in Uzbekistan ed., Tashkent 2013, 304-308. http://www .erasmusplus.uz/files/downloads/book_ tempus_iv_2013.pdf

RHUSTE Tempus project. History and Culturology. Russian Tuning/ECTS-based educational models for the implementation of the Bologna Process in Human Sciences (Cheliabinsk State University: Cheliabinsk 2008). http://tuningacademy. org/wp-content/uploads/2014/02/RHUSTE_Booklet-for-the-Subject-areas-ofHistory-and-Culturology.pdf.

Roy. Olivier. The New Central Asia. The Creation of Nations. (New York, London: I.B. Tauris, 2000; reprint 2007: The New Central Asia. The Birth of Nations; French orig.: La Nouvelle Asie centrale ou la fabrication des nations (Paris: Editions du Seuil, 1997).

Russian Tajik (Slavic) University. http://www.rtsu.tj/rtsu/istoriya.

Smanaliev, Kynatbek, and Farida Ryskulueva. "Prospects of Development of the Higher Education in Kyrgyzstan and problems of joining the Bologna Process", Proceedings of the Tempus Regional Conference "Higher Education in Central Asia: Ongoing Reforms and Future Perspectives”, Tashkent, 22-23 November 2004, Aziza Abdurakhmanova, Claire Morel, Heather Mowbray, and Shokhida Safarova eds. http://eacea.ec.europa.eu/tempus/doc/tashkent_en.pdf, 68-80.

Soucek, Svat. A History of Inner Asia. (Cambridge: Cambridge University Press, $2000\left[2006,7^{\text {th }}\right.$ printing]).

The World Factbook 2013-14. (Washington, DC: Central Intelligence Agency (CIA), 2014): https:/www .cia.gov/library/publications/the-world-factbook/index.html

TuCAHEA (Tuning Central Asia). www.tucahea.org.

Tuning Educational Structures in Europe (Tuning Europe. http://www .unideusto.org/ tuningeu/).

- Final Report. Pilot Project - Phase I. (Bilbao and Groningen: University of Deusto Press, 2003).

Tuning project in Africa (Tuning Africa). http://www.tuningafrica.org/

Tuning project in China (Tuning China). http://tuningchina.org/

Tuning project in Georgia (Tuning Georgia). http://tuningacademy.org/tuninggeorgia/?lang=en

Tuning project in Latin America (Tuning Latin America). http://www.tuningal.org

- CLAR. Latin American Reference Credit (Bilbao: University of Deusto Press, 2013). http://www.tuningal.org/es/publicaciones/cat_view/48publications-in-english-books?start=15 
Tuning project in Lithuania (Tuning Lithuania). http://tuningacademy.org/tuninglithuania/?lang=en

Tuning project in Russia (Tuning Russia). http://tuningrussia.org/

- Reference Points for the Design and Delivery of Degree Programmes in Education, Ivan Dyukarev, Arlene Gilpin and Evgeniya Karavaeva eds. (Bilbao: University of Deusto Press);

Tuning project in USA (Tuning USA). http://tuningusa.org/

Umatova, Karligash. "Проект TuCAHEA: цели, пространство, участники, ожидаемые результаты”, Tempus IV in Uzbekistan 2013, National Tempus Office in Uzbekistan ed., Tashkent 2013, 309-313. http://www .erasmusplus.uz/ files/downloads/book_tempus_iv_2013.pdf

United Nations Educational, Scientific and Cultural Organization (UNESCO), Archive, entry for International Committee on Intellectual Cooperation (ICIC). http://biblio-archive.unog.ch/Detail.aspx?ID=408

- International Bureau of Education (IBE). http://www.ibe.unesco.org/en/ about-the-ibe/who-we-are/history.html

- History of Civilizations of Central Asia, vol. VI: Towards the contemporary period: from the mid-nineteenth to the end of the twentieth century, Chahryar Adle ed., Madhavan K. Palat and Anara Tabyshalieva co-eds. (Paris: UNESCO Publishing, 2005). http://unesdoc.unesco.org/images/0014/001412/141275e.pdf

United Nations. Composition of macro geographical (continental) regions, geographical sub-regions, and selected economic and other groupings. http:// www.cnbc.com/id/102166864

—. General Assembly. 90th plenary meeting, 12 December 1995, resolution A/ RES/50/80, 11 January 1996. http://www.un.org/en/ga/search/view_doc. asp?symbol=A/RES/50/80\&Lang $=\mathrm{E}$

United States Census Bureau, International Data Base. https:/www.census.gov/ population/international/data/idb/informationGateway.php

UZHELTH Tempus Project (Tuning Public Health in Uzbekistan). http://www. uzhelth.org

van der Meer, Ingrid and Ann Katherine Isaacs, Minutes of the Fourth TuCAHEA Plenary Conference and Working Meeting (Samarkand, 14-15 November 2014). Unpublished.

World Bank, GDP data for 2013. http://data.worldbank.org/indicator/NY.GDP. PCAP.CD. 